\title{
Problems and Suggestions on Implementation of Undergraduate Training Program for Innovation and Entrepreneurship
}

\author{
Lu Ling, Wang Li (corresponding author) \\ Jiangxi University of Traditional Chinese Medicine \\ wangli0550@163.com
}

\begin{abstract}
The purpose of this article is to enhance the quality and benefit of the undergraduate training program for innovation and entrepreneurship, upgrade education on innovation and entrepreneurship as well as cultivate talents in innovation and entrepreneurship. The method adopted in this article is to combine practices of undergraduate training program for innovation and entrepreneurship conducted at Jiangxi University of Traditional Chinese Medicine with questionnaires and interviews to study factors that influence the outcome of the training program. To conclude, various measures should be taken to improve the outcome of the training program and provide references for the program conducted in other universities, including change of application mode for project declaration, providing training guidance, complement management mode, building platform for practice and service as well as awarding outstanding projects.
\end{abstract}

Keywords-Undergraduating Training program for innovation and entrepreneurship; Quality; Value; Problems; Suggestions

\section{INTRODUCTION}

Ministry of Education issued, in 2010, Proposals on Promoting Education for Innovation and Entrepreneurship in Higher Education and on Undergraduate Independent Entrepreneurship. It says "It is an important way to deepen the higher education reform and cultivate students' innovation spirit and practice capabilities through education on innovation and entrepreneurship in higher education and encourage undergraduates to start their own businesses. [1]" Colleges and universities should serve as important fronts for cultivating talents of innovative and entrepreneurship and its position with this regard should be fully recognized and emphasized.

In 2011, Ministry of Education began to implement the National Undergraduating Training Program for Innovation and Entrepreneurship. At the same year, 16300 programs were declared in 109 colleges and universities directly under central ministries and commissions. Later, more colleges and universities joined the team. With the support from local governments and active participation of various colleges and universities, the programs were conducted with full speed. Up to now, the Undergraduate Training Program for Innovation and Entrepreneurship (UTPIE) has go beyond of schools, colleges or universities, provinces or even countries. UTPIE falls into three parts, namely, Innovation Training Program, Entrepreneurship Training Program and Entrepreneurship Practice Program

\section{INTRODUCTION ON UTPIES AT OUR UNIVERSITY}

Since 2012, our university has applied 200 UTPIEs, with 135 at national level and 65 at provincial level. In our university, there are 113 training programs for innovation, 68 training programs for entrepreneurship and 19 practice programs for entrepreneurship with 240 teachers and over 1000 students directly participating in those programs.

The training programs for innovation focus more on medicine major and related majors, such as Study on Extraction and Composition Mechanism of Certain Component of Traditional Chinese Medicine, Method Innovation on Extraction of Component, Study on Functions of Traditional Chinese Medicine etc. These programs are often sub-programs of instructors' study programs. Thus, they have certain study references and are usually conducted by individual students or a team of students with the instruction of an instructor. Students usually complete design, preparation of the study conditions, implementation of the program, writing study report, exhibition of and communication over achievements independently.

The difference between training programs for entrepreneurship and practice programs for entrepreneurship lies in that in the former, every student of the program team plays one or more roles during the implementation, simulates operating a company and participate in practice while in the latter, students conduct real entrepreneurial activities based on early training. Our university entrepreneurship programs fall into two big categories as shown in the following table:

Lu Ling, female, Jiangxi University of Traditional Chinese Medicine, master, instructor, study on Science of Higher Education, Science of Health Management.

Wang Li, male, corresponding author, Email: wangli0550@163.com.

The fund project: Jiangxi University of Traditional Chinese Medicine education reform project (2015jzjg-34) 
TABLE I. CATEGORIES AND EXAMPLES

\begin{tabular}{|c|c|c|c|c|c|}
\hline $\mathrm{C} 1$ & Examples & $\mathrm{C} 2$ & Examples & $\mathrm{C} 3$ & \\
\hline Software & $\begin{array}{c}\text { Study professional } \\
\text { knowledge of Traditional } \\
\text { Chinese medicine(TCM) }\end{array}$ & \multirow{5}{*}{$\begin{array}{l}\text { Campus } \\
\text { Service }\end{array}$} & $\begin{array}{c}\text { Secondhand } \\
\text { commodity trading }\end{array}$ & \multirow{5}{*}{ Others } & $\begin{array}{l}\text { Package for } \\
\text { medicine }\end{array}$ \\
\hline \multirow[t]{4}{*}{ E-business } & $\begin{array}{c}\text { Health consulting } \\
\text { /cervices }\end{array}$ & & Computer repair & & Health care \\
\hline & Publicity on TCM & & $\begin{array}{c}\text { Portrayal of } \\
\text { personal image }\end{array}$ & & $\begin{array}{c}\text { Translation on } \\
\text { TCM }\end{array}$ \\
\hline & $\begin{array}{c}\text { Psychological } \\
\text { counselling/treatment }\end{array}$ & & $\begin{array}{c}\text { Boiling TCM } \\
\text { service }\end{array}$ & & $\begin{array}{l}\text { Food waste } \\
\text { treatment }\end{array}$ \\
\hline & E-trade & & $\begin{array}{l}\text { Farm joy stay } \\
\text { Tutor agency, } \\
\text { logistics }\end{array}$ & & \\
\hline
\end{tabular}

\section{SIGNIFICANCE OF IMPLEMENTING UTPIES}

The primary purpose of implementing UTPIEs is not about the programs but is more about cultivating comprehensive quality of college or university students. Based on surveys through questionnaires on implementing the 200 declared UTPIEs, we learnt that most students agree that the implementation of these programs is of great help in promoting their comprehensive qualities, to be specific, way of thinking and capability for innovation and entrepreneurship, capability of teamwork and coordination, interpersonal communication, independent thinking, transfer theoretical knowledge into practical ability, independent study and time management [2].

On UTPIEs, programs are carriers where students conduct self and research study under the guidance of an instructor. And the study covers related sciences to compulsory courses required by the teaching plan. This is to say, colleges and universities have to change their education ideals, focusing more on cultivating talents through practices so as to raise talents of good practical, innovative and entrepreneurial capabilities. UTPIEs became catalyst to higher education reform and promoted reform of teachers in various aspects, such as teaching goals, content, methodologies and means.

Besides, aside from its education value on talent cultivation, UTPIEs also have great economic and social values [3]. The completion of a program does not mean the termination of its education purpose. Many programs after incubated successfully are docked with markets. It not only produces economic benefits but also provides jobs for college or universities students nearby.

\section{PROBLEMS DURING IMPLEMENTING UTPIES}

It has been six years since the first declaration of UTPIE in our university in 2012. As the management division, Higher Education Research Office accumulated lots of experience and meanwhile found some problems in this regard.

\section{A. Program structure and quality to be optimized}

Our university data tells us that nearly $60 \%$ of the programs are training programs for innovation while less than $10 \%$ are practice programs for entrepreneurship. Most training programs for innovation are just a division of an instructor's research while some were even researches of an instructor that have already been declared. The students are just lab workers in these programs, subordinated to their instructor's research, which goes in the opposite direction with the purpose of implementing UTPIEs. Besides, due to weak innovation and low-end entrepreneurial field, the programs for entrepreneurships are often cross over one another. Therefore, the programs lack of core competitiveness and the marketization rate of the program achievements is a bit low.

\section{B. Low enthusiasm in students}

To regulate the use of program fund, according to Measures for Fund Allocated to Program for Jiangxi University of Chinese Medicine Undergraduate Teaching Quality and Teaching Reform, the fund for UTPIEs goes directly to the account of the students' instructor on the program and later shall be used by students under the guidance of the instructor. When reimbursing the expenses, the students have to register such cost at Higher Education Research Office with the signature of their instructor. During the monitoring and supervision, we found that some reimbursed expenses are just registered in the name of students or were directly used by instructors, which severely damaged students; enthusiasm in participating in the programs. 


\section{Frequently replacing program members}

Our university adopt 2-year study period for UTPIEs above provincial level. The application of such UTPIEs are in the first half year and the result usually comes out in the second half year. In our application notice, we require the host for a program should be a sophomore or freshman (in terms of a 5year education, third-year student). During the final phase of such program, most students either study for the graduate entrance examination or take an internship or could not come to the debate for other reasons. Some even left the campus and dropped the program. As a result, the instructor has to look for new teams to take the place or finish the programs themselves. Frequently replacing program members can prohibit the successful execution and result of the program.

\section{Lack of instruction and training}

All UTPIEs give more attention to its application for declaration while instruction on the program is often overlooked. On one hand, most programs the instructors came across were researches, different from UTPIEs. And the instructors often graduated from science, lack of professional and systematic accumulation for entrepreneurship, which limits their instruction to the students. On the other hand, instructors' work per hour on the program is often insufficiently recognized. This leads to instructors' lack of motive in giving instruction for the program.

\section{E. Lack of regulation and supervision}

A three-level supervision mechanism is used for the management of UTPIEs in our university, including instructors, schools and university. In practice, the role of schools is not well played. A declaration review is called in in the first half year, a year later the mid-term inspection while the acceptance inspection for the completion of the program is usually in the second year. However, during actual inspection and acceptance, due to less ideal efficiency of the program, the review team usually has to lower their requirements and the rate of excellence among all program is less than $20 \%$.

\section{UTPIES MANAGEMENT OPTIMIZATION}

Management is a dynamic, circulating and complicated process. The following suggestions are put forward to improve the quality and outcome of UTPIEs and give the role of promoting cultivation of students' innovative and entrepreneurial capability into full play considering common problems in implementing the programs,

\section{A. Change of application mode}

To avoid repeated, overlapping and low-level application of UTPIEs, instructors for the programs are advised to be collected so that the instructor can participate in the application review with designed titles and designed programs. The management division should organize the review and the titles, abstracts and instructor contact of the chosen program should be announced publicly. Establish a mechanism in which instructors and students are allowed to select one another. Appoint a person in charge and that person will be responsible to recruit the team out of interest in the programs.

\section{B. Providing training guidance}

On one hand, strengthen curriculum construction such as Introduction to Innovation and Entrepreneurship so that every student at the university will have an opportunity to receive systematic and professional knowledge for innovation and entrepreneurship. On the other hand, instructions can be given to students in terms of lectures or practice activities where famous entrepreneurs, entrepreneurial instructors in and out of universities are invited and excellent practicing students come to share their successful cases and experience. Currently, Jiangxi province has build an instructor pool for higher education innovation and entrepreneurship. Colleges or universities can follow this example and hire well-known scientists, entrepreneurs, venture capitalist, successful business starters to be instructors for UTPIEs. Moreover, list training on instructors for UTPIEs as a special work in improving teachers' teaching capability.

\section{Management mode optimization}

Modify Undergraduate Training Program for Innovation and Entrepreneurship Management Measures to further clarify the management mode and uses of the program fund. Programs for Innovation are managed by Higher Education Research Office (or School of Innovation and Entrepreneurship). They will be under coordinated management considering the open hours of labs and the graduating paper design for undergraduates. Programs for Entrepreneurship are under unified management by the Youth League Committee (Department of Student Affairs Management) to fully display its advantage in close relationship with students. After the programs are declared, the three-level management including instructors, schools and the university will come into the management to enhance process management and follow up supervision and instruction in time. Adjust the research period of the programs from two years to one year to guarantee the sustainable and successful implementation of the programs.

Based on past experience, during implementing the UTPIEs, some students would quit, some instructors would quit or programs would be shut down. Thus, it is necessary to establish a program exit mechanism. Based on actual situation, a certain portion of UTPIEs are allowed to be terminated before it completion while the rest of the fund should be gathered to the fund pool for UTPIEs to support the incubation of programs of bigger potential and value.

\section{Establishing practice and service platform for innovation and entrepreneurship}

High attention should be given to the practicality and applicability of cultivating talents for innovation and entrepreneurship. Therefore, it is particularly important to build a practice platform for innovation and entrepreneurship, such as society activity platform, scientific competition platform, innovation laboratory platform, internship and practice platform in and out of university, startup incubation park platform so as to create a thick entrepreneurial environment.[4]Besides, establishment of entity and on-line service platform for innovation and entrepreneurship can provide guidance on enterprise rules and policies and promotion services on programs for entrepreneurship, 
effectively docking mass entrepreneurship platform and facilitating sustainable development of UTPIEs.

\section{E. Awarding excellent programs}

Select excellent programs that have been completed and accepted. Publish their achievements on Higher Education Research and Practice on Chinese Herbal Medicine and exhibit them on display board for communication under unified organization of the Higher Education Research Office. Outstanding student teams should be given score reward. Excellent instructors should be awarded in terms of teaching achievements. Encourage excellent programs to be improved and participate in various competitions on innovation and entrepreneurship. Meanwhile, give them financial support for participating in the competition and grant them cash reward once their programs win any prize.

\section{CONCLUSION}

Education on Innovation and Entrepreneurship is a spiritual education through which one gets self-development through practice and it is of strong practicality and applicability. It is now entering into a new development phase while traditional theoretical teaching can hardly satisfy the needs of innovative and entrepreneurial talent cultivation and innovation and entrepreneurship industrial upgrading. The mode of "Theory + Training + Practice" is the right one to go with the innovation and entrepreneurship education reality. UTPIE is an important carrier to conduct education for innovation and entrepreneurship and has great significance and obvious effects in cultivating comprehensive quality of undergraduates, changing higher education talents cultivation concept and promoting reform in higher education teaching. It receives great attention from various levels, including students, higher education, local government and national government. Take measures from perspectives of program application mode, training guidance, management mode, service platform and reward system so as to create good conditions for incubating more quality programs for innovation and entrepreneurship and provide more quality and experienced talents for innovation and entrepreneurship.

\section{REFERENCES}

[1] Ministry of Education. Proposals on Promoting Education for Innovation and Entrepreneurship in Higher Education and on Undergraduate $\begin{array}{lll}\text { Independent } \quad \text { Entrepreneurship. } & \text { [EB/OL]. }\end{array}$ http://www.zjsme.gov.cn/newzjsme/list.asp?id=35619

[2] Zhang Xiaoyong, Fan Lu, Wang Ying, Gao Peng, Yin Ran, Liu Dantong. Surveys and Studies on the Influence of Innovation and Entrepreneurship Trainings to Undergraduates' Capability for Innovation and Entrepreneurship [J]. Education on Chinese Herbal Medicine, 2005,34(04): 51-54

[3] Gao Yang. Study on Sustainable Development of Undergraduate Training Program for Innovation and Entrepreneurship. [D]. Dalian University of Technology. 2016.

[4] Dai Qiuhua, Zhang Zengnian. Build Practice Platform for Innovation and Entrepreneurship, Improve Undergraduates' Capability of Innovation and Entrepreneurship------Take Zhejiang Wanli University for Example [J]. Education Forum, 2012, (33): 51-53. 